Journal Of Ageing And Family (JOAF)

Edition 1, No 1, October 2021

\title{
Literature Review : \\ Determinant Factors Of Elderly Participation To Posbindu In Indonesia
}

\author{
Sinta Fitriani, Fenty Agustini,Dadan Yogaswara \\ Public health STIKes Respati \\ taniesa1571@gmail.com
}

\begin{abstract}
The low participation of the elderly in Posbindu can cause serious problems both for the elderly themselves and for their families. Health conditions that are not monitored and risk factors for PTM that are not detected directly can increase morbidity and even lead to death. While poor health conditions in the elderly, often sick can be a burden for family members. This study aims to determine the factors associated with the participation of the elderly to Posbindu in Indonesia. Method used in this research is a descriptive literature review study. Where in this method, researchers use search techniques, analyze and combine facts from various credible related sources. The sources in question are various research results that have been published previously. The analysis is carried out by searching various scientific articles or related journals published on Google Scholar with a publication range of the last five years starting from 2016 - 2020. Based on the results of the study, there were 2 out of 9 journals that stated that the age factor, gender and work factor, 3 of 9 journals stated that the attitude factor and motivation factor, 5 out of 9 journals stated that the knowledge factor, 1 out of 9 journals stated that the distance factor and policy, 5 out of 9 journals mentioning that family support factors, 2 out of 9 journals that mention that the motivational factor and 3 out of 9 journals that stated that the role of health workers was related to the participation of the elderly in posbindu. Conclusion of this study is that there are many factors that influence the participation of the elderly to Posbindu where of the 12 behavioral factors related to participation, knowledge and family support are the most dominant factors affecting the participation of the elderly to Posbindu in Indonesia.
\end{abstract}

Keywords : Predisposing factors, Enabling factors, Reinforcing factor, Participation, Posbindu

\section{A. INTRODUCTION}

Based on the Law of the Republic of Indonesia No. 36 of 2009 concerning Health and Law No. 13 of 1998 concerning the Welfare of Elderly Citizens (elderly), health promotion for the elderly is one of the government programs that aims to maintain and improve the health status and abilities of the elderly, so that their physical, mental and social conditions can function properly, through counseling and dissemination information on health for the elderly, efforts to cure (curative), which is expanded to the field of geriatric/gerontological services, development of care institutions for the elderly who suffer

http://ejournal.urindo.ac.id/index.php/JournalOfAgeingAndFamily/index 
from chronic diseases and/or terminal diseases (1).

Elderly Posyandu is an integrated service post for the elderly community that has been agreed upon, which is driven by the community where they can get health services (Sulistyorini, 2010). In addition, the Elderly Posyandu also provides social services, religion, skills, sports and arts and culture as well as other services needed by the elderly in order to improve the quality of life through improving their health and welfare. In addition, they can be active and develop their potential (2).

The activities of the elderly posyandu that run well will provide convenience for the elderly in obtaining basic health services, so that the quality of life of the elderly is maintained properly and optimally. The activity of the elderly in Posbindu can provide great benefits

\section{B. RESEARCH METHOD}

Method used in this research is a descriptive literature review study. Where in this method, researchers use search techniques, analyze and combine facts from various credible related sources. The sources in question are various research results that have been published previously.

The analysis is carried out by searching various scientific articles or related journals published on Google Scholar with a publication range of the last five years starting from 2016 - 2020. Searching for scientific journals or articles is carried out using keywords or keywords participation, elderly and posbindu. The criteria to consider in choosing a journal include: 1 ) open or free access journal/publication, 2) relevant to the topic to be researched, 3) a full text article/journal. The variables studied in this study are the factors that affect the activeness of elderly visits to the elderly posyandu.

The stages are as follows:

\section{Literature Search Strategy}

a. Framework used The for their health conditions. The benefits obtained by the elderly if they are active in Posbindu activities are: their health condition will always be monitored regularly, the elderly get counseling related to PTM risk factors and do physical activities together to improve body fitness (3).

The low participation of the elderly in Posbindu can cause serious problems both for the elderly themselves and for their families. Health conditions that are not monitored and risk factors for PTM that are not detected directly can increase morbidity and even lead to death. While poor health conditions in the elderly, often sick can be a burden for family members. This study aims to determine the factors associated with the participation of the elderly to Posbindu in Indonesia.

Framework used in this study is the PICO method. The PICO method is a clinical information search method which is an acronym for 4 components: P (patient, population, problem) namely elderly participation in posbindu I (intervention, prognostic factor, exposure) namely participation factor C (comparison, control) namely routine visits and $\mathrm{O}$ (outcome) namely non-routine visits

b. Keywords used

The keywords used in the literature review search are Factors, participation, elderly, posbindu

c. Database or application used Search is performed using Google Scholar. The search was carried out by entering all the words in the title of the literature review "Factors, participation, elderly, posbindu into livelihoods. The articles found were read carefully to see if the articles met the author's inclusion criteria to be used as literature in writing a literature review. Time-limited income from 2016 to 2020 accessed in fulltext in pdf format.

http://ejournal.urindo.ac.id/index.php/JournalOfAgeingAndFamily/index 
Tabel 1 Eligibility Criteria

\begin{tabular}{|c|c|c|}
\hline \multicolumn{2}{|l|}{ Searchingarticles } & Google Scholar \\
\hline \multicolumn{2}{|l|}{ Keyword } & $\begin{array}{l}\text { Factors, } \\
\text { participation, } \\
\text { elderly, posbindu }\end{array}$ \\
\hline \multicolumn{2}{|l|}{ Research Locations } & Indonesian \\
\hline \multicolumn{2}{|l|}{ Limits } & $2016-2020$ \\
\hline \multicolumn{2}{|c|}{ Access to documents } & $\begin{array}{l}\text { Tthat can be } \\
\text { accessed Fulltext in } \\
\text { Pdf Format. }\end{array}$ \\
\hline \multirow[t]{2}{*}{ Inclusion Criteria } & Research Original (Not Literature review) & \\
\hline & Target: Mothers of toddlers $0-59$ months & \\
\hline
\end{tabular}

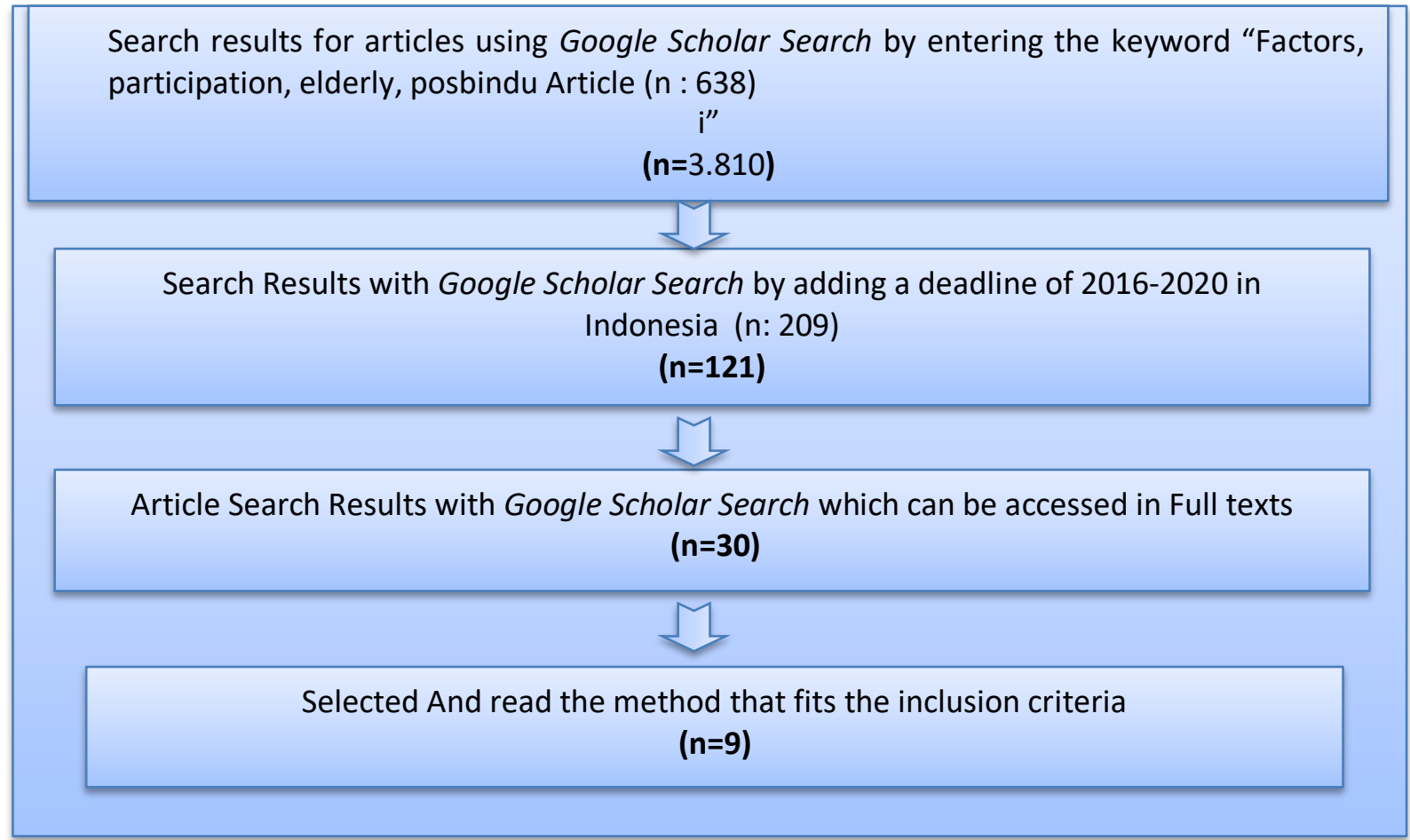

2. Inclusion Criteria:
a. All articles related to elderly participation in posbindu
b. Articles for 2016 - 2020
c. Accessible full text

\section{Study Search and Selection Results}

Articles included in the inclusion criteria are analyzed, extracted and synthesized and then the evidence is determined. From the results of the extraction and analysis, it is hoped that a conclusion can be found that can be used as a basis for conducting interventions in the community setting.

The following is the essence of the research: title of research, name of researcher, year of publication, methods, results and complete research conclusions with significant values. The extracted digests are then entered in a table so that the

http://ejournal.urindo.ac.id/index.php/JournalOfAgeingAndFamily/index 
extraction results are easy to read. After selection based on inclusion criteria, 13 articles were obtained and then analyzed.

\section{RESEARCH RESULTS AND DISCUSSION}

Table 2 article search results

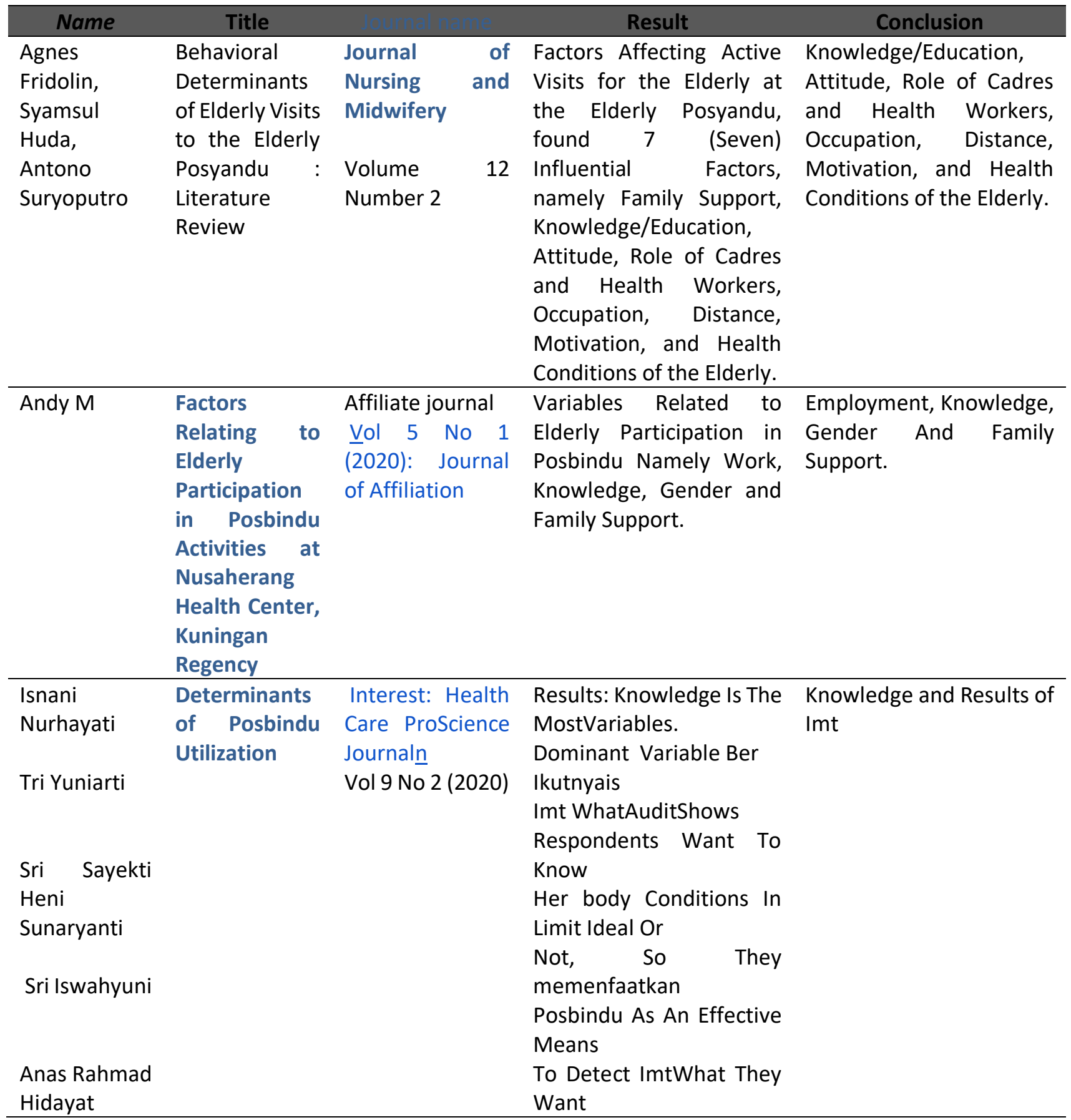

http://ejournal.urindo.ac.id/index.php/JournalOfAgeingAndFamily/index 


\begin{tabular}{|c|c|c|c|c|}
\hline & & & 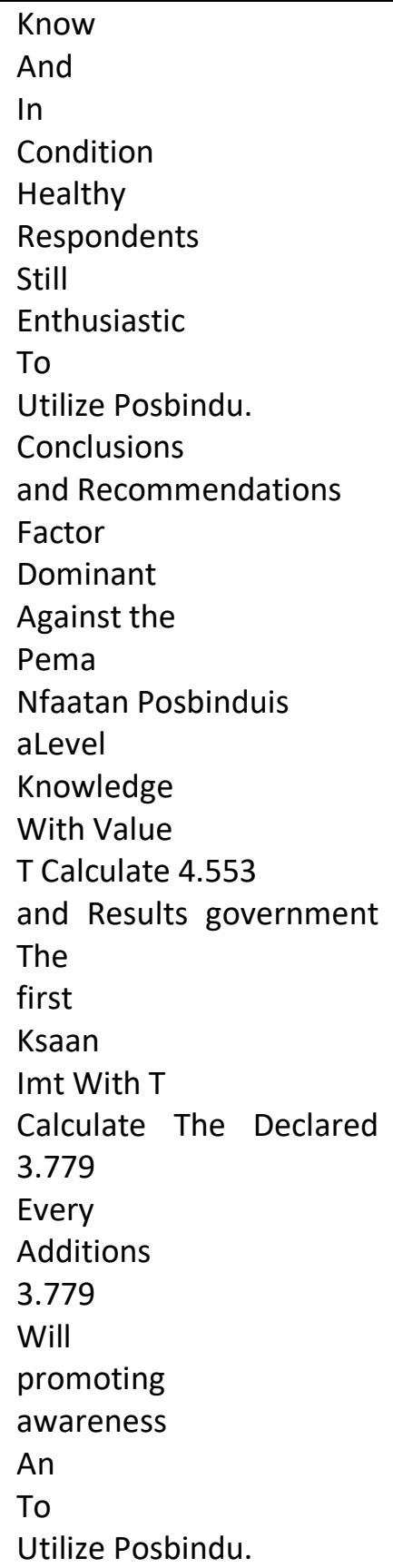 & \\
\hline $\begin{array}{l}\text { Melita1, } \\
\text { Mardiati } \\
\text { Nadjib2 }\end{array}$ & $\begin{array}{l}\text { Factors } \\
\text { Related } \\
\text { toVisits to the } \\
\text { ElderlyElderly } \\
\text { Posbindu in } \\
\text { the Work Area } \\
\text { of the Health } \\
\text { Center in }\end{array}$ & $\begin{array}{l}\text { Indonesian } \\
\text { Health Policy } \\
\text { Journal : JKKI } \\
\text { Volume } 07 \\
\text { of } 2018\end{array}$ & $\begin{array}{l}\text { Predisposing Factors } \\
\text { Associated with } \\
\text { Elderly Visits to Elderly } \\
\text { Posbindu Are } \\
\text { Knowledge. } \\
\text { Supporting Factors } \\
\text { Associated With } \\
\text { Elderly Visits To Posbindu } \\
\text { Elderly Namely }\end{array}$ & $\begin{array}{l}\text { Knowledge. } \\
\text { Family Support And } \\
\text { Family Support Officer } \\
\text { The Need for }\end{array}$ \\
\hline
\end{tabular}




\begin{tabular}{|c|c|c|c|c|}
\hline & $\begin{array}{l}\text { Bintara Village, } \\
\text { Bekasi City in } \\
2017\end{array}$ & & $\begin{array}{l}\text { Family Support And } \\
\text { Support OfOfficers } \\
\text { Family. } \\
\text { Needs Factors Are } \\
\text { Significantly Relate } \\
\text { To Elderly Visits To } \\
\text { Posbindu Elderly. } \\
\text { Informants Who Visit } \\
\text { Posbindu } \\
\text { Elderly Need Posbindu } \\
\text { Elderly To } \\
\text { Get Health Services And } \\
\text { Can Socialize With Other } \\
\text { Elderly. }\end{array}$ & \\
\hline $\begin{array}{l}\text { Septi } \\
\text { Anggraeni } \\
\text { Erfina } \\
\text { Fauziah }\end{array}$ & $\begin{array}{l}\text { Determinants } \\
\text { of Utilization } \\
\text { of Posbindu } \\
\text { Ptm in Uwie } \\
\text { Village } \\
\text { Working Area } \\
\text { of Muara Uya } \\
\text { Health Center } \\
\text { Tabalong } \\
\text { Regency }\end{array}$ & $\begin{array}{l}\text { Vol. } 10 \text { No. 2: } \\
\text { December } 2020\end{array}$ & $\begin{array}{l}\text { That Knowledge, } \\
\text { Attitudes and Perceptions } \\
\text { of Family Support Affect } \\
58 \% \text { of the Utilization of } \\
\text { Posbindu Ptm. }\end{array}$ & $\begin{array}{l}\text { Knowledge, Attitudes and } \\
\text { Perceptions of Family } \\
\text { Support }\end{array}$ \\
\hline $\begin{array}{l}\text { Jeane } \\
\text { Sumendap, } \\
\text { Sefti Rompas, } \\
\text { Valen Check } \\
\text { out }\end{array}$ & $\begin{array}{l}\text { Relationship } \\
\text { between } \\
\text { Family } \\
\text { Support and } \\
\text { Motivation } \\
\text { with Elderly } \\
\text { Interests in } \\
\text { Posbindu }\end{array}$ & $\begin{array}{l}\text { Journal of } \\
\text { Nursing } \\
\text { Vol 8, No } 1(2020\end{array}$ & $\begin{array}{l}\text { There is a relationship } \\
\text { between family support } \\
\text { and motivation with the } \\
\text { elderly's interest in } \\
\text { Posbindu in Tumaluntung } \\
\text { Village, with a family } \\
\text { support value of } P=0.05 \\
\text { while a motivation value } \\
\text { of } P=0.01 \text {. }\end{array}$ & $\begin{array}{l}\text { Family support and } \\
\text { motivation with interest } \\
\text { in the elderly }\end{array}$ \\
\hline $\begin{array}{l}\text { Angga Satria } \\
\text { Pratama, } \\
\text { Agus Miraj } \\
\text { Darajat }\end{array}$ & $\begin{array}{l}\text { Characteristics } \\
\text { of the elderly } \\
\text { who visit } \\
\text { Posbindu in } \\
\text { the work area } \\
\text { of Upt } \\
\text { Panghegar, } \\
\text { Bandung }\end{array}$ & $\begin{array}{l}\text { Idea Nurshing } \\
\text { Journal }\end{array}$ & $\begin{array}{l}68.7 \% \text { who actively visit } \\
\text { Posbindu are female, } \\
68.8 \% \text { who actively visit } \\
\text { Posbindu are aged (56-65 } \\
\text { years), and } 57.8 \% \text { of } \\
\text { elderly who visit } \\
\text { Posbindu are } \\
\text { unemployed, and a total } \\
\text { of } 78.1 \% \text { Inactive Elderly } \\
\text { Visits Posbindu Elderly. }\end{array}$ & $\begin{array}{l}\text { Gender } \\
\text { Age of } \\
\text { Work }\end{array}$ \\
\hline
\end{tabular}


Journal Of Ageing And Family (JOAF)

Edition 1, No 1, October 2021

\begin{tabular}{|c|c|c|c|c|}
\hline $\begin{array}{l}\text { Sri Sundari } \\
\text { Putri Mentari }\end{array}$ & $\begin{array}{l}\text { Factors } \\
\text { Relating to } \\
\text { Elderly } \\
\text { Participation } \\
\text { in the Elderly } \\
\text { Posyandu }\end{array}$ & $\begin{array}{l}\text { Journal } \\
\text { Midwifery } \\
\text { Vol. } 2 \text { No. } 2 \\
\text { (2016): } \\
\text { Edition }\end{array}$ & $\begin{array}{l}\text { Age, } \\
\text { Employment, Income, } \\
\text { Health Resources, Health } \\
\text { Facilities, Family Support, } \\
\text { Community Support and } \\
\text { Government Policy are } \\
\text { Factors Related to Elderly } \\
\text { Participation in Elderly } \\
\text { Posyandu. }\end{array}$ & $\begin{array}{l}\text { Age, Education, } \\
\text { Employment, Income, } \\
\text { Health Resources, Health } \\
\text { Facilities, Family Support, } \\
\text { Community Support and } \\
\text { Government Policies }\end{array}$ \\
\hline $\begin{array}{l}\text { Putri } \\
\text { Mindianata }\end{array}$ & $\begin{array}{l}\text { Factors } \\
\text { Influencing } \\
\text { the Active } \\
\text { Intentions of } \\
\text { the Elderly in } \\
\text { Participating } \\
\text { in the Elderly } \\
\text { Posyandu }\end{array}$ & $\begin{array}{l}\text { Health } \\
\text { Promotion } \\
\text { Journal } \\
\text { Vol 6, No } \\
(2018)\end{array}$ & $\begin{array}{l}\text { Attitude to Behavior } \\
\text { Affects Respondent's } \\
\text { Intention to Actively } \\
\text { Participate in Elderly } \\
\text { Posyandu with Value (Sig. } \\
0.008 \text { ) }\end{array}$ & Attitude \\
\hline
\end{tabular}

Based on the table above, it is stated that the participation of the elderly to posyandu is influenced by several factors including:

\section{Predisposing factors consisting of:}

\section{a. Age}

Based on the results of the study, there were 2 out of 9 journals that stated that the age factor was related to the participation of the elderly in posbindu. The results of this study are supported by the results of research conducted by Purnawati in 2014 which stated that age is a factor that affects elderly visits in posyandu activities in Plumbon Village, Mojolaban District, Sukoharjo (4).

Research conducted by Lestari in 2011 confirms the results of this study where the age factor affects elderly visits to posbindu. In this study, it was stated that the elderly aged $>70$ years were more active in coming to the posyandu because they often felt health problems (5).

\section{b. Gender}

Based on the results of the study, there were 2 out of 9 journals that stated that the gender factor was related to the participation of the elderly in posbindu. The results of this study are in accordance with research conducted by Harianto (2004) in Ningsih, et al. (2014) which states that gender differences affect the use of health services, including activities for fostering elderly health. Meijer (2009) in Ningsih, et al. (2014), stated that women are easier to accept advice and advice fromworkers health, this is what causes women to more easily cope with various health problems, so that they can improve their quality of life by visiting and using the posyandu for the elderly to check their health (6) .

\section{c. Employment}

Based on the research, there are 2 out of 9 journals that mention that the work factor is related to the participation of the elderly in posbindu.

The theory presented by Andersen (1975) in Priyoto (2014) which states that work is a predisposing factor that can influence a person in utilizing health services (7).

This study is in line with research conducted by Rosyid, et al. (2009) which states that

http://ejournal.urindo.ac.id/index.php/JournalOfAgeingAndFamily/index 
work is a factor that influences elderly visits to the elderly health coaching post where elderly people who do not work are better at utilizing elderly health coaching activities. Respondents who work will be busier so they have less time to attend in elderly health coaching activities compared to respondents who do not work (8).

\section{d. Attitudes}

In this study, 3 of 9 journals stated that the attitude factor was related to the participation of the elderly in posbindu.

According to Notoatmojo (2007) in Yuniati (2012), elderly people who have a positive attitude towards elderly health development activities tend to be more active in visiting health coaching posts (9).

\section{e. Knowledge and education}

Based on the results of the study, 5 out of 9 journals stated that the knowledge factor was related to the participation of the elderly in posbindu. Meanwhile, 2 out of 9 journals stated that educational factors were related to elderly participation in posbindu.

This is in line with research conducted by Pertiwi, which states that there is a relationship between the frequency of presence of the elderly in the elderly posyandu and knowledge (10).

Furthermore, Mengko stated that the level of good knowledge possessed by the elderly made respondents more active in utilizing posyandu as much as 5.9 times greater than the knowledge that was not good (11).

\section{f. Motivation}

Based on the research, there are 3 out of 9 journals stating that motivational factors are related to the participation of the elderly to posbindu. The motivation of the elderly is a factor that cannot be separated from the needs so that the motivation of the elderly is very important for the elderly themselves to encourage the elderly to do something when they feel there is a need. So that it can be interpreted that the elderly who have good motivation will be encouraged to participate in activities carried out by the posyandu and the elderly can have their health checked at the posyandu so that the health of the elderly can be monitored properly (12).

\section{Enabling factors consisting of:}

\section{a. Distance}

Based on the research, 1 out of 9 journals stated that the distance factor was related to elderly participation in posbindu. Based on the results of Aryantiningsih's (2014) research in Pekanbaru City, it was stated that respondents who lived close to the elderly posyandu had a 2.13-fold chance to utilize the elderly posyandu compared to respondents who lived far away (13).

\section{b. Policy}

In this study, 1 of 9 journals stated that the policy factor was related to the participation of the elderly in posbindu. This is in accordance with the Director General of Community Health Development (Kemenkes 2012) stating that the government has formulated policies, programs and activities for the elderly. The purpose of the elderly program is to improve the health status of the elderly so that they remain healthy, independent and efficient so that they do not become a burden for themselves, their families and the community. The aspects developed are to slow down the aging process (degenerative). For those who feel old, they need to be restored (rehabilitated) in order to be able to carry out their daily lives independently (14).

\section{Reinforcing factor}

\section{a. Family support}

There are 5 out of 9 journals mentioning that family support factors are related to elderly participation in posbindu. According to 
Akhmadi (2009) in Pratiwi, et al. (2014), efforts to encourage the interest or willingness of the elderly to participate in health development activities, family support is needed. The family can act as a strong motivator for the elderly if they are lazy to come to the health coaching post, always provide themselves to accompany or take the elderly to the posyandu, remind the elderly if they forget the posyandu schedule, and try to help overcome all problems with the elderly (15).

The results of this study are in line with research conducted by Kurniati (2014) which states that the factors that influence the low utilization of posyandu for the elderly (elderly) in Kedondong Village, Sokaraja District, Banyumas Regency are family support (16).

Sunartyasih's research in 2011 stated that family support was related to elderly visits to posbindu. According to Friedman (2008) that the family functions as a support system for its members. This support can be done by increasing the emotional, rewarding, instrumental, and informative support provided by family members (17).

\section{b. The role of cadres}

There are 2 out of 9 journals that mention that the motivational factor is related to the participation of the elderly to posbindu. According to Wiyono (2000), good cadre services can affect the activeness of elderly visits to the elderly health coaching post. Good interactions with mutual respect, respect, responsiveness, and attention can instill trust and credibility from the elderly towards cadres. If the relationship between cadres and the elderly is good, then health coaching activities can take place more effectively. In contrast, the elderly who are treated poorly tend to ignore the advice and advice of cadres or will no longer want to come to the elderly health coaching activities (18).

\section{c. The role of health workers}

Based on the results of the study, there were 3 out of 9 journals that stated that the role of health workers was related to the participation of the elderly in posbindu.

Pertiwi (2013) defines the elderly will use the service depending on the assessment of the service. If the service is not good or of less quality, then the tendency to not use it will be even greater. Perception of service is always associated with satisfaction and expectations of service users. Consumers say that service quality is good if their expectations and desires are in accordance with the experience they receive (19).

The results of this study are in line with Lestari's research (2011) that good service for cadres and health workers is proven as a factor that affects the activeness of elderly visits to the elderly posyandu. Quality health services from the point of view of patients and society means empathy, respect, and responsiveness to their needs. In general, people want services that reduce symptoms effectively and prevent disease so that they and their families are healthy and can carry out their daily tasks without physical disturbance. Widjajono's research (2009) states that the service of officers has a significant and positive effect on the participation variable. (20)

\section{CONCLUSIONS AND RECOMMENDATIONS}

Conclusion of this study is that there are many factors that influence the participation of the elderly to Posbindu where of the 12 behavioral factors related to participation, knowledge and family support are the most dominant factors affecting the participation of the elderly to Posbindu in Indonesia.

So it is recommended that health workers improve health promotion programs related to posbindu services for the health of the elderly and posbindu cadres can motivate families to be able to encourage and assist

http://ejournal.urindo.ac.id/index.php/JournalOfAgeingAndFamily/index 
the elderly during health checks at the posbindu.

\section{E. ACKNOWLEDGMENTS}

Acknowledgments are given to STIKes Respati as a provider of facilities for

\section{F. REFERENCES}

1. Law No. 36 of 2009 concerning Health. State Gazette of the Republic of Indonesia Year 2009, No. 5063. Secretariat of State. Jakarta

2. Soeweno, Inten. (2010). Guidelines for the Implementation of the Elderly Posyandu. Jakarta: National Commission for the Elderly.

3. Sulistyorini. (2010). Posyandu and village alert. Yogyakarta : Nuha Medika

4. Indonesian Ministry of Health. 2014. General Guidelines for Integrated Development Post for NonCommunicable Diseases. Jakarta: Ministry of Health, Republic of Indonesia.

5. Purnawati, N. Factors Affecting Elderly Visits in Posyandu Activities in Plumbon Village, Mojolaban District, Sukoharjo [Thesis]. Nursing Study Program, Faculty of Health Sciences, Muhammadiyah University, Surakarta. 2014. From http://eprints.ums.ac.id

6. Lestari, Puji., Hadisaputro, Soeharyo., \& Pranarka, Kris. (2011). Several Factors Contributing to Active Elderly Visits to Posyandu Case Study in Tamantintro Village, Kasihan District, Bantul Regency, DIY. Media Medika Indonesia , 45 (2) : 79-80.

7. Ningsih, R., Aneliwati., \& Lestari $W^{\prime}$ Factors Affecting Elderly Interests in Visiting the Elderly Posyandu'. Online Journal of Nursing Students [Online], 2014. vol. 1, no. 2, p. 1-10. From download.portalgaruda.org

8. Priyoto. Theory of Attitudes and Behavior in Health. Yogyakarta : Nuha Medika.2014. conducting research activities and the extended family of researchers who have provided moral and material encouragement.

9. Rosyid, F Nur., Uliyah M., \& Hasanah U. Factors Influencing Elderly Visits to the Elderly Posyandu in Rw VII Wonokusumo Village, Semampir District, Surabaya. Faculty of Health Sciences, University of Muhammadiyah Surabaya. 2009. From journal.um-surabaya.ac.id

10. Yuniati, F., Dewi, Y. Utilization of the Elderly Posyandu in the Working Area of the Kertapati Health Center in 2012. 2009.

From journal.poltekkespalembang.ac.id

11. Pertiwi, HW 2013. Factors Associated with the Frequency of Elderly Attendanceat the Elderly Posyandu. Prada Midwife: Journal of Midwifery Publication Akbid YLPP Purwokerto,4(01): 15.13.I

12. Mengko, VV 2015. Utilization of Posyandu for the Elderly in the Working Area of Teling Atas Health Center, Manado City. IF YOU,5(5): 479-490

13. Sekarningrum, et al. The Relationship of Motivation and Family Support with Elderly Visits to the Posyandu at the Sempaja Health Center. Borneo Student Research. elSSN: 2721-5725, Vol 2, No 1, 2020

14. Aryantiningsih, DS. 'Factors Relating to Utilization of Posyandu Elderly in Pekanbaru City'. Journal of Public Health [on line], 2014. vol 1, No. 2, p. 42-47. From http://ojs.uniska-bjm.ac.id/

15. Indonesian Ministry of Health. 2012. Indonesian Health Profile. Jakarta: Ministry of Health RI.

16. Pratiwi, EN., Rumiyati, E., \& Wijayanti. 'The Relationship between Family Support and Intensity of Elderly Visits to 
the Barokah Elderly Posyandu in the hamlets of Mainland Kepoh Tohu and Colomadu aranganyar'. Journal of Kesmadaska [on line], 2014. vol.5, no.2, pp.146-150.

From journal.stikeskusumahusada.ac.id

17. Kurniati, C Hadi. Factors Affecting the Low Utilization of Posyandu for the Elderly (Elderly) in Kedondong Village, Sokaraja District, Banyumas Regency.Study MidwiferyProgram DIII Faculty of Health Sciences, University of Muhammadiyah, Purwokerto. 2014. From seminarlppm.ump.ac.id

18. Sunartyasih, R., \& Linda, B. (2011). The Relationship between Posbindu Implementation Constraints and the Presence of the Elderly in Posbindu RW.08 Palasari Village, Cibiru District, Bandung City. Proceedings of
SNaPP2012 : Science, Technology and Health. ISSN 2089-3582

19. Wiyono D. 'Quality Approach and Customer Satisfaction in Health Services'. Journal of Health Service Quality Management, 2000. vol 1, pp. 346. Airlangga University.

20. Pertiwi, Herdini W. 2013. Factors Associated with the Frequency of Elderly Attendance at the Elderly Posyandu. Boyolali: AKBID Estu Utomo. Scientific papers.

21. Widjajono, Urip. 2009. Elderly Participation in Posyandu Plus Activities in Soragan Ngestiharjo Hamlet, Poor Bantul. Surakarta : Mpower. Surakarta State University. Thesis

http://ejournal.urindo.ac.id/index.php/JournalOfAgeingAndFamily/index 